\title{
Factors Affecting the Quality of Working Life: An Enquiry into the RMG Industry of Bangladesh
}

\author{
Kaniz Marium Akter*, Subrata Banik \\ Department of Business Administration, Mawlana Bhashani Science and Technology University, Tangail, Bangladesh \\ Email address: \\ kanizmakter@gmail.com (K. M. Akter),subratamgt@gmail.com (S. Banik) \\ ${ }^{*}$ Corresponding author \\ To cite this article: \\ Kaniz Marium Akter, Subrata Banik. Factors Affecting the Quality of Working Life: An Enquiry into the RMG Industry of Bangladesh. \\ Journal of Human Resource Management. Vol. 6, No. 1, 2018, pp. 26-36. doi: 10.11648/j.jhrm.20180601.14
}

Received: February 26, 2018; Accepted: March 13, 2018; Published: April 4, 2018

\begin{abstract}
The aim of this study is to investigate the quality of working life (QWL) of RMG industry in Bangladesh. It identified the factors that affect the work life of RMG employees. A quantitative research design was applied that used 100 structured questionnaires, filled up by the employees from 20 RMG companies of Dhaka EPZ. The findings indicate that companies already ensured the satisfactory working environment, but in the quality issue, working lives of RMG employees are not as healthy as expected. The results expose errors and faults of authorities in QWL issues. Therefore, it is an attempt to create awareness among the authorities for formulating new policies. A small sample is used, in the study, from Dhaka EPZ; therefore, care is required when generalizing the results. This study forms a base for conducting research in future on the impact of QWL on employee productivity.
\end{abstract}

Keywords: Quality of Working Life (QWL), RMG Companies, RMG Employees, Dhaka EPZ, Bangladesh

\section{Introduction}

Bangladesh is now the second largest apparel and textile exporting country that helped Bangladesh economy to ensure middle income status in the world. It is the largest foreign exchange earning sector that occupied (FY 2016-17) 81.23\% of the country's annual export [1]. In this year, 4482 RMG factories were in operation that employed around 4 million people [2]. And female workers hold most of the jobs about $80 \%$ [3]. Bangladesh has also maintained a healthy $7 \%$ plus growth rate in last year and significantly reduced the number of absolute poor. The industry played the main role, where Bangladesh is eying at earning USD 50 billion through RMG exports by 2021 [4].

However, RMG industry has been deeply shocked by the tragedy of Tampaco Foils Limited, Rana Plaza and Tazreen Fashions etc. when the industry faces considerable challenges by way of compliance requirements. Bangladeshi industries have been plagued by allegations of low wages and lax safety measures. According to the writ petition of Tampaco fire, the explosion took place due to violation of relevant Laws. Government has since put much effort to improve workplace safety. Actually, all those accidents have brought the issue of workplace safety to the fore and led all stakeholders to act accordingly. Following the unfortunate incidents, all members of the concerned authority (like BGMEA and BKMEA) are working to carry out the corrective action plans and investing huge amount of money in this regard. Experts are examining how workplaces and work can be reformed so that life in factories befits the dignity of man.

In 1996, an unusual strike occurred at the General Motors assembly plant at Lords town, Ohio [5]. It is called unusual because the strike was in protest against the monotonous work and the authoritarian management. They were demanding better quality in their working life, which is a new set of values and a new way of thinking. Research findings indicate that Quality of Working Life and productivity go hand in hand [6,7]. Through gain in productivity, managers can reduce costs, save scarce resources, and improve profits. The improved profits, in turn, allow an organization to provide better pay, benefits, and working conditions.

Quality of working life (QWL) refers to the favorableness or unfavorableness of a job environment for the people working in an organization. Sometimes, QWL is 
interchangeably termed as humanizations of work, industrial democracy, and participative work. It is concerned with taking care of the higher-order needs of employees in addition to their basic needs. The American Society of Training and Development (1979) defines QWL as a process of work organizations which enable its members at all levels to actively participate in shaping the organizations environment, methods and outcomes. This value based process is aimed towards meeting the twin goals of enhanced effectiveness of organizations and improved quality of life at work for employees. QWL is viewed as that umbrella under which employees feel fully satisfied with the working environment and extend their wholehearted cooperation and support to the management to improve productivity and work environment. Basic objectives of an effective QWL program are improved working conditions (employees' perspective) and greater organizational effectiveness (employers' perspective). A win-win situation may result if QWL is positively linked to business performance. QWL can nurture a more flexible, loyal and motivated workforce, which is essential in determining a company's competitiveness.

With the increasing shift of the economy towards knowledge economy, the meaning of QWL has undergone a drastic change. The traditional management gave inadequate attention to human values where workers are treated as commodity or cog of machine. But, needs and aspirations of the employees are now changing. They want safe and healthy working environment, and dignity and empowerment. They are aware of what is happening around the world because of mass media. The situation may get more complicated, if necessary measures are not taken beforehand. Modern managers are facing a complex problem in seeking the ways to improve the quality of working life; because it is difficult to identify the attributes that ensure QWL. Hence, this study takes into consideration the exploration of the factors that affect the QWL and their impacts in the RMG industry due to its ever-increased role in the economy of Bangladesh.

\section{Objectives of the Study}

The objectives of this research are as follows:

2.1 to examine the present scenario of QWL prevailing in the RMG industry of Bangladesh;

2.2 to address the factors that influence the QWL of the RMG workers; and

2.3 to find out the flaws and operational problems regarding the QWL issues in the RMG industry of Bangladesh.

\section{Review of the Literatures}

QWL is one of the most important organizational equipment, to improve organizational performance and to reduce employee turnover, which should be applied for job satisfaction, job design and job enrichment [8]. Basic objective of ensuring a healthy work life is the improved working condition as well as the greater organizational effectiveness. It is evident that there is a direct and significant relationship between job performance and QWL in all aspects $[9,10]$ tested a theoretical model of the relationship between employees' QWL and their intention to leave the organization. An inverse relationship between employees' QWL and their turnover intention is found.

QWL may be viewed as a wide ranging concept that includes satisfaction towards work, participative management and improved work environment. Table 1 lists some of the components of QWL as viewed by the scholars in various type of organization.

Table 1. Components of QWL in the View of Different Researchers.

Walton (1975)

Stein (1983)

Levine et al. (1984)

Mirvis and Lawler (1984)

Baba and Jamal (1991)

Hui-ru (1994)

Lau and Bruce (1998)

Ellis and Pompli (2002)

Jia-sheng and Jing-li (2003)

Hai-wei (2003)

Saraji and Dargahi (2006) adequate and fair compensation, safe and healthy working conditions, immediate opportunity to use and develop human capacities, opportunity for continued growth and security, social integration in the work organization, constitutionalism in the work organization, work and total life space, social relevance of work life autonomy or being independent, being recognized and prized, belongings, progression and development, external reward respect from supervisor and trust on employee's capability; change of work, challenge of the work, future development opportunity arising from the current work, self-esteem, scope of impacted work and life beyond work itself, contribution towards society from the work

safe work environment, equitable wages, equal employment opportunities, opportunities for advancement, opportunities to learn and grow, protection of individual rights job satisfaction, job involvement, work role ambiguity, work role conflict, work role overload, job stress, organizational commitment, turn-over intentions living quality: compensation, welfare, work safety, work protection; social quality: the relationship with the boss, colleagues, and customers; growth quality: participation management, promotion, self-growth, self-esteem and work characteristic job security, reward systems, training, career advancements opportunities, participation in decision in decision making poor working environments, resident aggression, workload, inability to deliver quality of care preferred, balance of work and family, shiftwork, lack of involvement in decision making, professional isolation, lack of recognition, poor relationships with supervisor/peers, role conflict, lack of opportunity to learn new skills working environment, salary and bonus, welfare, promotion, work nature, training and development, leadership style of the boss, cooperation among colleagues, enterprise image, communication, organizational regulations, organization climate and culture, working time and workload needs for survival, needs for passion, needs for belonging, need for self fair pay and autonomy, job security, reward systems, training and career advancements, opportunities, participation in decision making, interesting and satisfying work, trust in senior management, recognition of efforts, health and safety standards at work, balance between the time spent at work and the time spent with family and friends, amount of work to be done, level of stress experienced at work, occupational health and safety at work 


\begin{tabular}{ll}
\hline Rose et al. (2006) & career satisfaction, career achievement, career balance \\
& work related task: work autonomy, importance of the tasks, feedback on work, significance of the work; organizational \\
Tao et al. (2007) & $\begin{array}{l}\text { environment: team spirit, interpersonal relationship, management style; social psychology: social and psychological support, } \\
\text { mutual respect, social image of the enterprise, economic position } \\
\text { fair and adequate pay and benefits rights, observance of safety and health factors, opportunities to continue growth and } \\
\text { security of staff, acceptance work organization, work life and social dependence on society and individual life, governing the } \\
\text { overall living space in the environment, integration of social improved human abilities }\end{array}$ \\
\hline
\end{tabular}

Source: Adopted from Nanjundeswaraswamy and Swamy [11]

Mirkamali and Thani [12] modified Walton's factors to determine the QWL among faculty members of Universities. At the same time, Bolhari et al. [13] used Walton's factors to measure the level of QWL in information technology staffs in Iran. Talebi et al. [14] examined the relationship between the employees' QWL and effectiveness of service organization. Seven QWL variables are considered - healthy and secured work environment, salary and benefits, job security, autonomy at work, skills education, and job development direction. Anwar et al., [15] revealed the most frequently used QWL drivers - reward, benefits and compensation, followed by career development, communication, and safety and security. They also identified some other important QWL drivers, like top management involvement, cohesion of work and life, job satisfaction and employee motivation. Subhashini and Gopal [16] used eight dimensions to evaluate status of QWL of women employees working in selected garment factories in Tamilnadu. The dimensions are relationship with coworker, opinion about workload, health and safety measures, satisfaction about feedback given, opinion about working hours, training programs, opinion about workplace, and grievance handling procedure.

Sharma and Verma [17] examined the existence of QWL in Small-scale Industries by identifying seven variables - good working environment, job satisfaction, chance of growth, fair compensation, employees' motivation, communication flow, and flexible or suitable working time. Reddy and Reddy [18] used nine dimensions to measure QWL in public and private banks like - emoluments, safe and healthy working conditions, social integration, social relevance of work, constitutionalism, opportunities to develop human capabilities, career planning, growth and development, work with job enrichment and organization structure. Haque et al. [19] conducted a study to assess the satisfaction level of garment workers on the QWL in Bangladesh. The factors include compensation, health and safety effort, work load, career growth opportunity, working environment, job design, informal relationship, and participation in decision making. The findings indicated that employees of garments sector neither disagree nor agree in the QWL initiatives by authority.

\section{Research Methodology}

A total of 100 employees from 20 RMG companies, operating in the Dhaka Export Processing Zone (DEPZ), were interviewed by a small team of interviewers. Of the 20 RMG companies, 5 employees from each company were randomly selected as respondents of the study. The sample size decision was based on cost and time considerations.

Although, the RMG employees were the main source of the required data, this study utilized multiple techniques to assemble data from the field. The interview schedule by a structured questionnaire, the observation, and the discussion (with managerial people) techniques were used. The terms and issues in the questionnaire were constructed after reviewing the relevant literatures. The questionnaire was developed in English and afterwards translated into Bengali for better understanding of the RMG employees. The questionnaire consisted a set of personal questions to better understand the demographic condition of the population.

Identification of the factors of QWL depends on the nature of the industry as well as on the characteristics of the respondents. Since it is a fully manufacturing industry where physical labor is required mainly, the influencing factors of QWL are identified after studying the prior research. After studying the relevant literatures, 6 factors - fair payment, job security and safety, leave and holiday benefits, career growth opportunities, work environment, and social and psychological support - were selected for studying the RMG employees' work life. Under those factors, 21 statements were made for rating by using a five-point Likert scale, where 1 means strongly disagree, 2 means disagree, 3 means neutral, 4 means agree, and 5 means strongly agree. In addition, 6 'yes/no questions' were placed for getting more ideas of their work life. Printed and published materials were also used as the secondary sources of data. The collected data were initially fed into and processed by the SPSS-20 software. Descriptive Statistics were prepared for defining the identified factors, after processing the data.

\section{Analysis of Demographic Characteristics of Population Surveyed}

The respondents were from different organizations, with different personal characteristics, of different economic conditions, with different job profiles, and with different views and perceptions. As shown in Table 2, a huge number of female workers are engaged in the RMG industry which is observed in the frequency of their responses (75\%). A greater portion of RMG employees are younger in their age, because $64 \%$ respondents were of '21-30 years' age range. This data confirms that comparatively younger people are contributing the industry actively. $64 \%$ of respondents with SSC validates that a larger portion of RMG employees are still not much educated. 
The number of family members gives data of RMG employees' economic condition, where the tradition of smallsized family is observed by $59 \%$ responses for 1 to 3 persons' family. Yet, 4 to 6 persons' family are also existed in a moderate number by $32 \%$. RMG employees' economic conditions were again explored by asking the number of earning member(s) in each family, where 1 person dependent family was evident by $74 \%$, and 2 persons dependent family was $20 \%$. From among the respondents only $2 \%$ were residing in slums, which would be an indicator of economic development of a country. This statement can be authenticated by the rate of pacca ghor residents (81\%), although $96 \%$ respondents were residing in the rental house, and only $4 \%$ were owned their home. Another important issue of RMG employees was observed by their way of transportation, because it influences employees' not only on the economic condition but also on the physical and mental health that ultimately impacts their productivity. Table 2 shows that $43 \%$ respondents commuted either by rickshaw or by bicycle, $48 \%$ commuted by public bus, and $9 \%$ commuted by walk.

Table 2. Demographic Characteristics of Population Surveyed.

\begin{tabular}{|c|c|c|c|c|c|}
\hline Characteristics & Demographics & Frequency & $\%$ & Valid \% & Cumulative \% \\
\hline \multirow{2}{*}{ Gender } & Male & 25 & 25 & 25 & 25 \\
\hline & Female & 75 & 75 & 75 & 100 \\
\hline \multirow{4}{*}{ Age } & Below 20 years & 6 & 6 & 6 & 6 \\
\hline & $21-30$ years & 64 & 64 & 64 & 70 \\
\hline & $31-40$ years & 22 & 22 & 22 & 92 \\
\hline & $41-50$ years & 8 & 8 & 8 & 100 \\
\hline \multirow{3}{*}{ Education } & Primary Level & 12 & 12 & 12 & 12 \\
\hline & HSC Level & 21 & 21 & 21 & 97 \\
\hline & Others & 3 & 3 & 3 & 100 \\
\hline \multirow{4}{*}{ Marital Status } & Married & 81 & 81 & 81 & 81 \\
\hline & Unmarried & 16 & 16 & 16 & 97 \\
\hline & Widowed & 1 & 1 & 1 & 98 \\
\hline & Divorced & 2 & 2 & 2 & 100 \\
\hline Number of Family Members & $1-3$ persons & 59 & 59 & 59 & 59 \\
\hline \multirow{3}{*}{ Number of Wage Earners } & 1 person & 74 & 74 & 74 & 74 \\
\hline & 2 persons & 20 & 20 & 20 & 94 \\
\hline & 3-4 persons & 6 & 6 & 6 & 100 \\
\hline \multirow{4}{*}{ Nature of Residence } & Slums & 2 & 2 & 2 & 2 \\
\hline & Katcha ghor & 5 & 5 & 5 & 7 \\
\hline & Pacca ghor & 81 & 81 & 81 & 88 \\
\hline & Building & 12 & 12 & 12 & 100 \\
\hline \multirow{3}{*}{ Ownership of residence } & Rental & 96 & 96 & 96 & 96 \\
\hline & Own & 4 & 4 & 4 & 100 \\
\hline & Govt. Land & 0 & 0 & 0 & 100 \\
\hline \multirow{3}{*}{ Nature of Conveyance } & Walk & 9 & 9 & 9 & 9 \\
\hline & Bus & 48 & 48 & 48 & 57 \\
\hline & Private Vehicles & 43 & 43 & 43 & 100 \\
\hline \multirow{2}{*}{ Tenure of Services } & $0-5$ years & 46 & 46 & 46 & 46 \\
\hline & $5-10$ years & 32 & 32 & 32 & 78 \\
\hline \multirow{5}{*}{ Gross salary (Monthly) } & Below 10,000 & 28 & 28 & 28 & 28 \\
\hline & $10,000-15,000$ & 49 & 49 & 49 & 77 \\
\hline & $15,000-20,000$ & 8 & 8 & 8 & 85 \\
\hline & $20,000-25,000$ & 7 & 7 & 7 & 92 \\
\hline & Above 25,000 & 8 & 8 & 8 & 100 \\
\hline \multirow{4}{*}{ Working hours (Daily) } & 8 hours & 71 & 71 & 71 & 71 \\
\hline & 10 hours & 19 & 19 & 19 & 90 \\
\hline & 12 hours & 10 & 10 & 10 & 100 \\
\hline & Above 12 hours & 0 & 0 & 0 & 100 \\
\hline
\end{tabular}

Source: Authors' Calculation through SPSS Analysis

A high rate of employee turnover in this industry was observed, since $78 \%$ of employees were engaged in their jobs for below 10 years. Only 3\% were performing their jobs in the same organization for above 15 years. It might be the cause of their poor salary structure, where $28 \%$ people were earning below BDT 10,000, 49\% were earning below BDT
15,000 , and only $15 \%$ people were earning above BDT 20,000 . However, most of the companies $(71 \%)$ made people engaged for work for 8 hours, while a number of companies employed people for 10 hours and even 12 hours (as normal work day) that is directly the violation of ILO Convention. 


\section{Research Findings}

\subsection{Work Life Amenities in RMG Industry}

Manufacturing industries especially where gathering of people is absolute, some tangible and intangible benefits compulsorily be provided to make their work life comfortable, as per Bangladesh Labour Act, 2006. By considering this issue, respondents were asked whether they have had the following amenities (as shown in Table 3). For better understanding of the existence of these amenities, data are also exhibited in below (Figure 1).

Table 3. Availability of Work Life Amenities.

\begin{tabular}{lll}
\hline Questions & Yes & No \\
\hline 1. Does your organization encourage you to join in the trade union? & $29 \%$ \\
2. Is there any common room and/or prayer room in your organization? & $100 \%$ \\
3. Have you ever been harassed/insulted/teased inside your organization? & $60 \%$ \\
4. Have you ever been harassed/insulted/attacked by stalkers in the roads? & $67 \%$ & $41 \%$ \\
5. Does your organization provide the maternity benefits, like paid leave? & $49 \%$ \\
6. Is there any child care center in your organization? & $3 \% \%$ & $7 \%$ \\
\hline
\end{tabular}

Source: Authors' Calculation through SPSS Analysis

Although the RMG firms are operating in the DEPZ, all employees were not encouraged to be unionized that is indicated by (No) $71 \%$. A very positive response was observed in the issue of the existence of common and/or prayer room by (Yes) 100\%. Some companies are giving maternity benefits only to the upper-level and permanent female employees that vary from 2 weeks to 3 months. A few RMG firms established their own child care center cum indoor playground, where only upper-class employees' children might be taken care of.

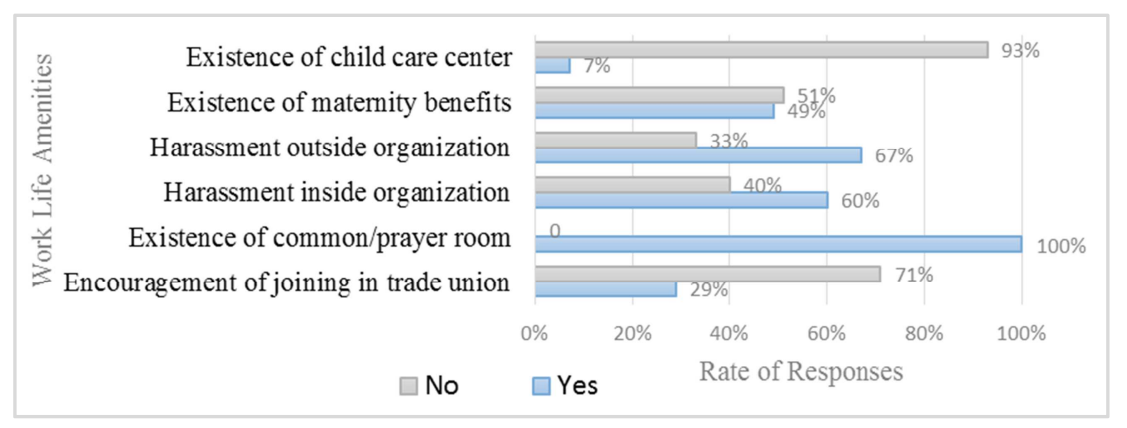

Figure 1. Rate of Availability of Work Life Amenities.

Finally, the term harassment got the equal priority as other amenities, because it negatively impacts both male and female employees. In this issue, $60 \%$ responded positively who were harassed within the organization either by immediate supervisor, or by colleagues, or by others. Specifically, female workers are sexually harassed by their co-workers in the factory or by police or by mastans in the street [20]. Later, $67 \%$ replied who were harassed outside the organization either by stalkers, or by vehicle's staffs, or by others.

\subsection{Factors of QWL in RMG Industry: Definition and Data Interpretation}

\subsubsection{Fair Payment}

Fair or equal pay is a principle of non-discrimination in compensation for work, i.e. pay should be based on the kind and quality of work done; and not according to the age, race, sex, religion, political association, ethnic origin, or any other individual or group characteristics. In this study, Fair Payment gets the top priority as a factor of QWL, since the industry is manufacturing in nature and physical labors are required first.

Table 4. Fair Payment: Descriptive Statistics.

\begin{tabular}{|c|c|c|c|c|c|}
\hline & $\mathbf{N}$ & Min. & Max. & Mean & Std. Deviation \\
\hline S_1. The wages policies of my organization are logical & 100 & 1 & 5 & 2.47 & 1.020 \\
\hline S_2. I get adequate payment for my job & 100 & 1 & 5 & 3.58 & 1.265 \\
\hline $\mathrm{S} \_3$. There is no wage discrimination in my organization & 100 & 1 & 5 & 2.22 & .836 \\
\hline Valid N (listwise) & 100 & & & & \\
\hline
\end{tabular}

Source: Authors' Calculation through SPSS Analysis

In the issue of fair payment, $\mathrm{S} 2$ shows the highest mean value (3.58), where employees perceived that they were adequately paid and they were in 'neutral to agree' position. But S_1 and S_3 indicate their disagreement, because they considered that the wages policies are not so logical as it should be and they were the victims of discrimination regarding the payment issue. 


\subsubsection{Job Security and Safety}

Employee needs such an assurance that s/he can keep his/her job without the risk of becoming unemployed; even if necessity arises, s/he can get rid of any short and long-term financial problems.

Table 5. Job Security and Safety: Descriptive Statistics.

\begin{tabular}{|c|c|c|c|c|c|}
\hline & $\mathbf{N}$ & Min. & Max. & Mean & Std. Deviation \\
\hline S_4. I feel quite secured in my job & 100 & 1 & 5 & 3.29 & 1.465 \\
\hline S_5. My organization provides social security benefits & 100 & 1 & 5 & 1.85 & .999 \\
\hline Valid N (listwise) & 100 & & & & \\
\hline
\end{tabular}

Source: Authors' Calculation through SPSS Analysis

A very different scenario is seen in Table 5, where results of S_4 and S_5 show the varied nature of the industry. Here, employees were moderate in the question of their job security (3.29), but they were afraid of the long-term financial coverage (1.85) which is termed as social security benefit.

\subsubsection{Leave and Holiday Benefits}

There is generally an agreement between the employer and employee about vacation, holiday, severance, or sick pay, meal or rest periods, holidays off, or vacations. In this study, employee's flexible work time option is also considered in the Leave and Holiday Benefits factor.

Table 6. Leave and Holiday Benefits: Descriptive Statistics.

\begin{tabular}{|c|c|c|c|c|c|}
\hline & $\mathbf{N}$ & Min. & Max. & Mean & Std. Deviation \\
\hline S_6. I get required paid leave from my organization & 100 & 2 & 5 & 4.52 & .731 \\
\hline $\mathrm{S}^{-}$7. I can enjoy all the holidays with payment & 100 & 2 & 5 & 4.50 & .785 \\
\hline S_8. My organization allows me flexible time options & 100 & 1 & 4 & 1.87 & .812 \\
\hline Valid N (listwise) & 100 & & & & \\
\hline
\end{tabular}

Source: Authors' Calculation through SPSS Analysis

In the question of adequate paid leaves and paid holidays, employees were 'agree to strongly agree' position that is displayed by the mean value 4.52 and 4.50 respectively. But they were not provided the flexible work schedule option, even where operation continues in more than one shift.

\subsubsection{Career Growth Opportunities}

Career growth makes an individual to perceive that organization creates an environment in which s/he is able to meet his/her career-related needs and reinforces those accomplishments through promotions and compensation, as [21] defined.

Table 7. Career Growth Opportunities: Descriptive Statistics.

\begin{tabular}{|c|c|c|c|c|c|}
\hline & $\mathbf{N}$ & Min. & Max. & Mean & Std. Deviation \\
\hline S_9. I find better career growth opportunity in my job & 100 & 1 & 5 & 1.83 & .792 \\
\hline $\mathrm{S} \_10$. Authority handles the promotion fairly & 100 & 1 & 5 & 2.13 & .837 \\
\hline S_11. My organization provides adequate training & 100 & 1 & 5 & 2.60 & 1.015 \\
\hline Valid N (listwise) & 100 & & & & \\
\hline
\end{tabular}

Source: Authors' Calculation through SPSS Analysis

Mean values of all the statements are not satisfactory, that are shown in Table 7, in the question of career opportunities. Specifically, except some upper-level jobs, there is no more chances of career development in the RMG industry. People even perceived that managers do not treat them fairly during placement and/or promotion. RMG companies provide some on-the-job training, although the training program is not sufficient.

\subsubsection{Work Environment}

An ideal workplace involves physical, geographical location as well as the immediate surroundings of the workplace (office building), and other factors, like - quality of air, noise level, and additional perks, benefits of employment and so on. This factor is essential for ensuring the safety in the workplace and for reducing the causes of accidents.

Table 8. Work Environment: Descriptive Statistics.

\begin{tabular}{|c|c|c|c|c|c|}
\hline & $\mathbf{N}$ & Min. & Max. & Mean & Std. Deviation \\
\hline S_12. The working hours that my organization asks for is good & 100 & 2 & 5 & 4.57 & .856 \\
\hline S_13. My organizational environment is good and motivating & 100 & 1 & 5 & 4.28 & .854 \\
\hline S_14. Physical environment always remains neat and clean & 100 & 1 & 5 & 4.41 & .767 \\
\hline $\mathrm{S} \_15$. Tools, machineries and electric appliances are regularly maintained & 100 & 1 & 5 & 3.99 & 1.210 \\
\hline S_16. I get medical facilities from my organization & 100 & 3 & 5 & 4.88 & .409 \\
\hline Valid N (listwise) & 100 & & & & \\
\hline
\end{tabular}

Source: Authors' Calculation through SPSS Analysis 
As per Table 8 , it is that factor of which overall mean value crossed 4 points. In the issue of work environment, people were very much delighted and they rated almost all the variables highly. They were happy to describe about medical facilities (4.88), working hours (4.57), physical environment (4.41) and moral health of the organization (4.28).

\subsubsection{Social and Psychological Support}

Employee seeks for perception or assistance of other people which is a part of a supportive social network. In any work environment, coworkers' and supervisors' support for employees' psychological and mental health are needed.

Table 9. Social and Psychological Support: Descriptive Statistics.

\begin{tabular}{|c|c|c|c|c|c|}
\hline & $\mathbf{N}$ & Min. & Max. & Mean & Std. Deviation \\
\hline S_17. Society treats my job nicely & 100 & 2 & 5 & 3.79 & 1.113 \\
\hline S_18. Managers communicate the necessary information on time & 100 & 1 & 5 & 4.74 & .747 \\
\hline S_19. I have a harmonious relationship with my colleagues & 100 & 4 & 5 & 4.60 & .492 \\
\hline S_20. I am satisfied with the attitude of my supervisor & 100 & 1 & 5 & 4.43 & 1.008 \\
\hline S_21. I am able to balance my work and personal life & 100 & 1 & 5 & 2.19 & .677 \\
\hline Valid N (listwise) & 100 & & & & \\
\hline
\end{tabular}

Source: Authors' Calculation through SPSS Analysis

In this factor, employees expressed their feelings of downward communicative culture (4.74), relationship with their coworkers (4.60), and relationship with their immediate and other supervisors (4.43) very positively, as the mean scores crossed 4. Also, they stated that society treats their job positively (3.79), yet they were sometimes frustrated due to the lack of balance of their personal and professional life (2.19).

\subsection{Impacts of the Factors of $Q W L$ : A Comparison}

Table 10 displays the descriptive statistics of the six factors that affect the quality of working life of RMG industry in Bangladesh. The statistics are analyzed by using mean score and standard deviation of those influencing factors in order to describe the basic features of QWL of RMG employees.

Table 10. Comparison among the Factors of QWL: Descriptive Statistics.

\begin{tabular}{|c|c|c|c|c|c|}
\hline & $\mathbf{N}$ & Minimum & Maximum & Mean & Std. Deviation \\
\hline Fair Payment & 100 & 1.33 & 4.33 & 2.76 & .66474 \\
\hline Job Security and Safety & 100 & 1.00 & 5.00 & 2.57 & .90459 \\
\hline Leave and Holiday Benefits & 100 & 2.00 & 4.67 & 3.63 & .49892 \\
\hline Career Growth Opportunities & 100 & 1.33 & 4.33 & 2.19 & .49988 \\
\hline Work Environment & 100 & 2.60 & 5.00 & 4.43 & .43545 \\
\hline Social and Psychological Support & 100 & 3.20 & 4.80 & 3.95 & .38178 \\
\hline
\end{tabular}

Source: Authors' Calculation through SPSS Analysis

The mean scores vary between 2.19 and 4.43 (Disagree to Agree) which state in the quality issue of work life, the perceptions of RMG employees were in between 'disagree to agree'. The values also mean that all the factors notably contribute to the work life of RMG employees in Bangladesh.

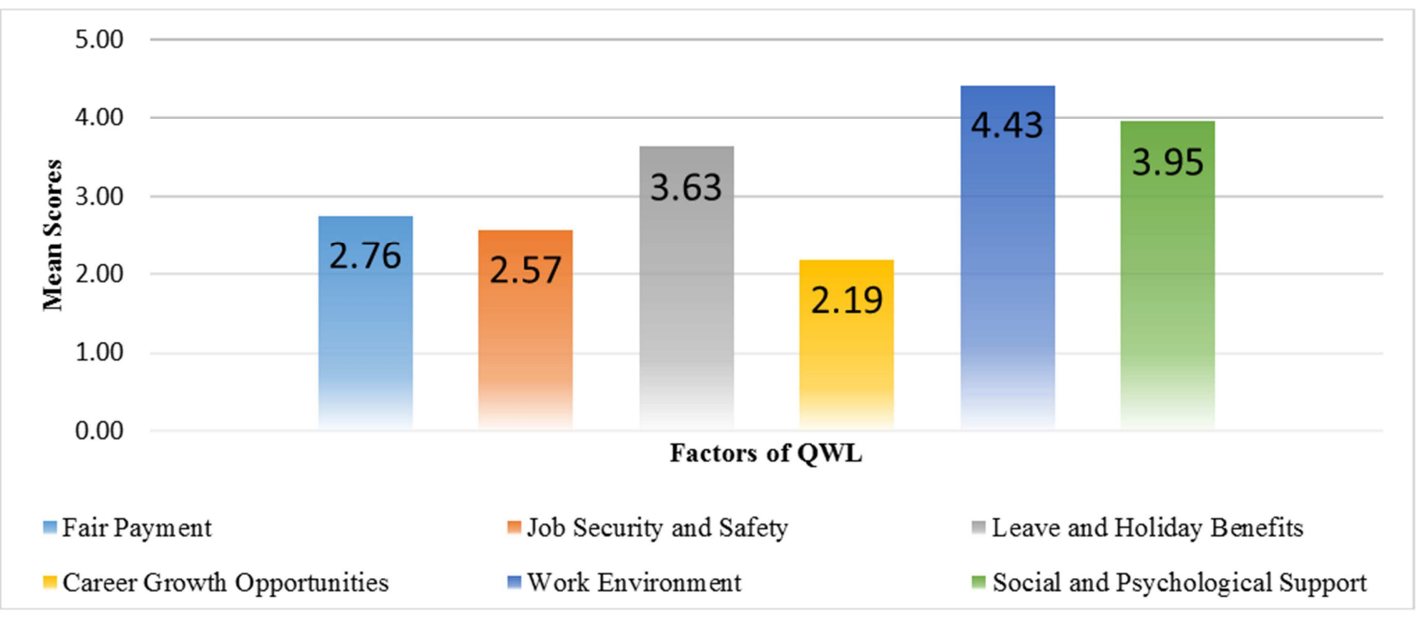

Figure 2. Comparison among the Factors of $Q W L$. 
If the mean score of the factors are compared and ranked, it is seen that the highest mean score lies in Work Environment (4.43), which is followed by Social and Psychological Support (3.95). Hence, the most contributing factor is Work Environment which is a key factor for ensuring a healthy work life. The least scores lie in Career Growth Opportunities (2.19), Job Security and Safety (2.57), and Fair Payment (2.76). Interestingly, Social and Psychological Support contributes more than other factors and that is followed by Leave and Holiday Benefits (3.63). Since all the factors, except Work Environment, did not touch 4 points, therefore RMG work life cannot be termed as healthy and/or full of quality.

\subsection{List of High-Score and Low-Score Variables}

After analyzing the results, separate two lists (in Table 11 and Table 12) are prepared that display the high-score variables and low-score variables. The lists are also presented in figures (Figure 3 and Figure 4) for getting the clear idea again. The variables are adopted from the statements of the previously stated six factors of QWL that were identified as S_1 to S_21 (Serial Number of Statement). For better understanding, the listed variables are appropriately addressed by the serial number of statement and the relevant factor. The scores are the mean values that are taken from the previous Tables.

Table 11. Five (5) Variables with the Lowest Values (Out of 5 Points).

\begin{tabular}{llll}
\hline Career Growth Opportunities & S_9 & Career Opportunity & 1.83 \\
Job Security and Safety & S_5 & Social Security Benefits & 1.85 \\
Leave and Holiday Benefits & S_8 & Flexible Time Options & 1.87 \\
Career Growth Opportunities & S_10 & Fair Promotion & 2.13 \\
Social and Psychological & S_21 & Work-Life Balance & 2.19 \\
Support & S_ & & \\
\hline
\end{tabular}

Source: Compiled by the Authors

Table 11 shows the variables with the lowest values that vary from 1.83 to 2.19 in a 5-point scale. Here, the lowest scored item is employees' career opportunities (1.83), which is closely followed by social security benefits (1.85), and flexible time options (1.87) in the RMG industry.

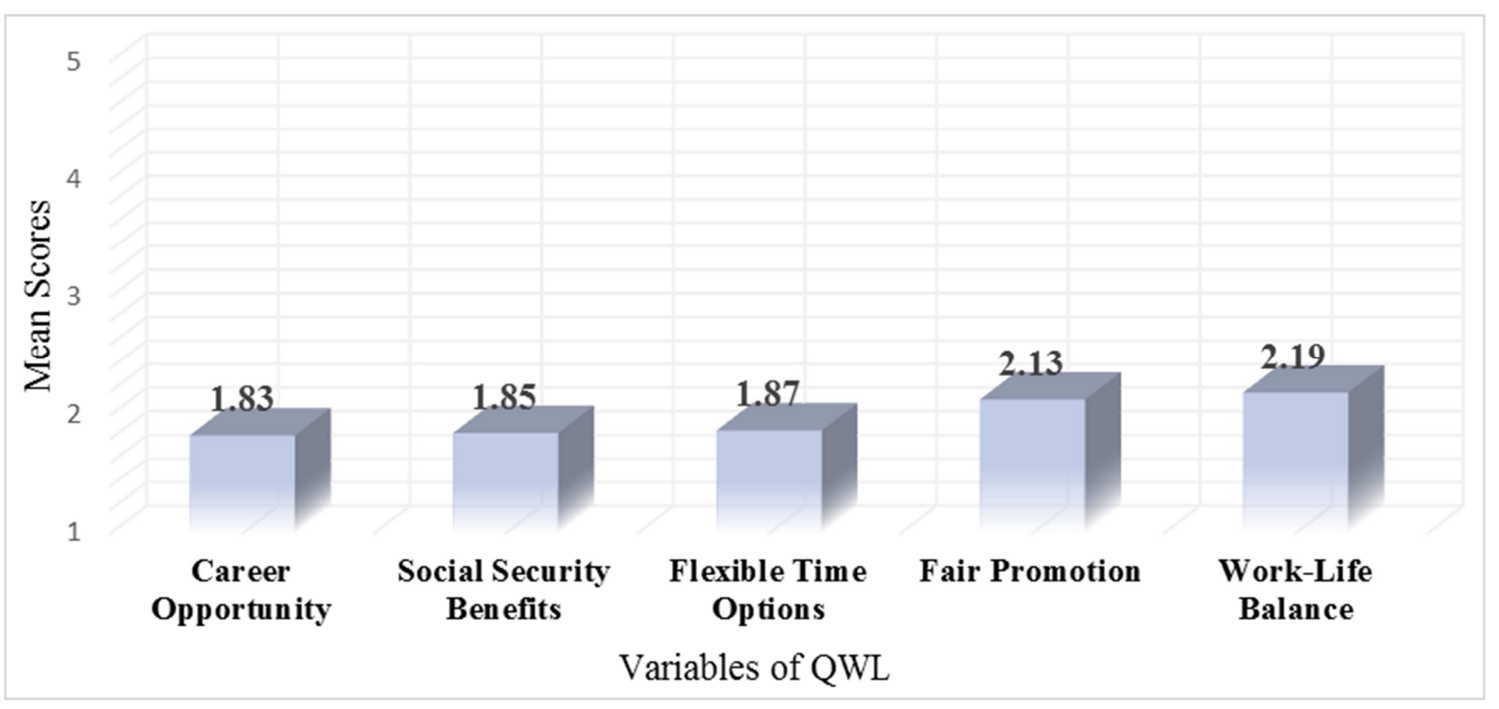

Figure 3. Variables with the Lowest Values.

Although fair promotion and work-life balance scored above 2, these components still are below the neutral position, i.e. almost 'disagree'. These variables might be the reasons of employee dissatisfaction, industrial conflict, employee turnover etc. in the RMG industry.

Table 12. Five (5) Variables with the Highest Values (Out of 5 Points).

\begin{tabular}{lll}
\hline Work Environment & S_16 & Medical Facilities \\
Social and Psychological Support & S_18 & Downward Communication \\
Social and Psychological Support & S_19 & Relationship with Colleagues \\
Work Environment & S_12 & Perception about Working Hours \\
Leave and Holiday Benefits & S_6 & Required Paid Leave \\
\hline
\end{tabular}

Source: Compiled by the Authors

Table 12 shows the variables with the highest values that varies from 4.88 to 4.52 in a 5-point scale. Here, the highest scored item is medical facilities provided by the organization (4.88), which is followed by downward communication culture (4.74). relationship with colleagues (4.60), perception about working hours (4.57) and having required paid leave (4.52) are also highly contributing items in the RMG industry. 


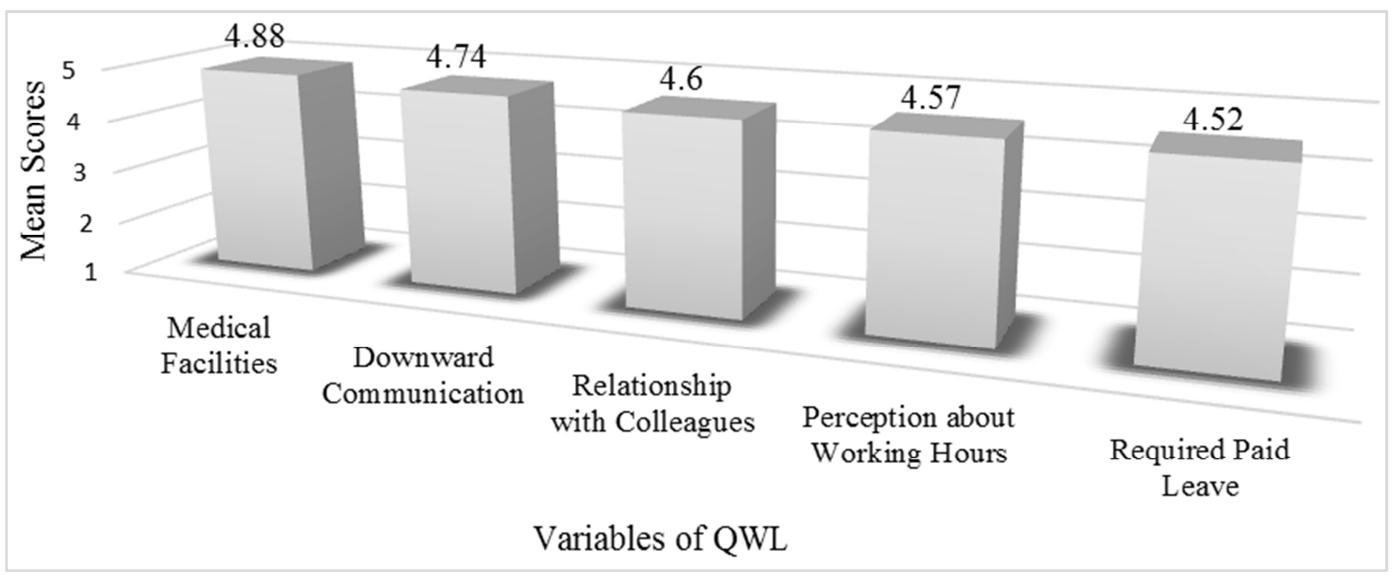

Figure 4. Variables with the Highest Values.

Figure 4 displays that all the variables crossed 4.50 , i.e. people were in between 'agree' to 'strongly agree' position. These variables ultimately result employee productivity, group cohesion, organizational engagement etc. in the RMG industry.

\section{Conclusions}

In coming years, global demand for RMG products is expected to surge where Bangladesh's RMG sector must continue to progress in compliance, infrastructure, and meager power capacities to take advantage of it. Besides, the industry needs to make a balance in its capability with workers' satisfaction so that they can be internally motivated to grab the potential global market demand. Concurrent incidents in this industry made the QWL as a burning issue. Modern industry makes QWL beyond its boundary by including the personal life where QWL ensures both motivation and satisfaction. The major focus of the study was to identify the factors affecting the QWL and their impacts in the RMG industry of Bangladesh. The study was concentrated in the prevailing conditions of work life of RMG employees that they are leading year after year.

The study results show that career growth opportunities were not effectively provided, whereas people got proper social and psychological supports from their surroundings. Importantly, they perceived that their working environment is good enough, but poor job security put them into an uncertain future. The results also show that most of the employees has got paid leave and holidays benefits but flexible time options need to be considered. Also, the absence of fair payment is an alarming issue, because it is primarily the basic need fulfilling element.

The results also show that majority were using public transports for commuting that might hamper a better and healthy working life of those workers. Because, abusive wording, harassment, attack and insult by stalkers and local goons in the road is a very common scenario. As most of the employees are female, results indicate that the lack of maternity benefits and harassment problem have negative impact on their work life. The vulnerable variables, like career opportunity, social security benefits, flexible time options, fair promotion and work-life balance were negatively found that need to be given greater attention to improve the prevailing conditions.

The study suggests to allow some work life amenities, like canteen facilities and/or subsidized foods; uniform to solve identity problems among employees; and transportation facilities (at least for vulnerable sections). These actions will help employees to adjust their cost of living too. In addition, if all the factors equally be considered in the RMG industry, it will ensure a very efficient and healthy working life which ultimately will create the employee commitment. This study was just the first phase in the identification of the influencing factors of QWL and their impacts in the RMG industry of Bangladesh. It will direct the future research on the impact of QWL on employee performance and/or organizational efficiency.

\section{Appendix}

Questionnaire on Factors of Quality of Working Life and Their Impacts: An Enquiry in the RMG Industry of Bangladesh

\section{A. Characteristics of Respondents}

\begin{tabular}{|c|c|}
\hline Name of the organization: & Organizational location: \\
\hline Name of the respondent: & Designation: \\
\hline Gender: a) Male b) Female & Age: \\
\hline \multicolumn{2}{|c|}{ Educational qualification: a) Illiterate b) Primary school c) Secondary school d) College e) Others } \\
\hline \multicolumn{2}{|c|}{ Marital status: a) Married b) Unmarried c) Widow d) Divorced } \\
\hline Number of family members: & Number of wage earners: \\
\hline Nature of residence: & Ownership of residence: \\
\hline a) Slums b) Katcha ghor c) Pacca ghor d) Building & a) Rental b) Own c) Govt. Land d) Quarter \\
\hline
\end{tabular}


Nature of conveyance: a) Walk b) Bus c) Private vehicle d) Company car

Tenure of service: a) Below 5 years b) 5-10 years c) 10-15 years d) Above 15 years

Gross salary (monthly): a) Below 10,000 b) 10-15,000 c) 15-20,000 d) 20-25,000 e) Above 25,000

Working hours (daily): a) 8 hours b) 10 hours c) 12 hours d) Above 12 hours

\section{B. Employees' Working Environment-related Information}

\begin{tabular}{lc}
\hline Questions & Yes \\
1. Does your organization encourage you to join in the trade union? \\
2. Is there any common room and/or prayer room in your organization? \\
3. Have you ever been harassed or insulted by anyone inside your organization? \\
4. Have you ever been felt harassed or insulted by local Slovenes or goons in the roads? \\
5. Does your organization provide the maternity benefits, like paid leave? \\
6. Is there any child care center in your organization?
\end{tabular}

\section{Employees' Working Life-related Information}

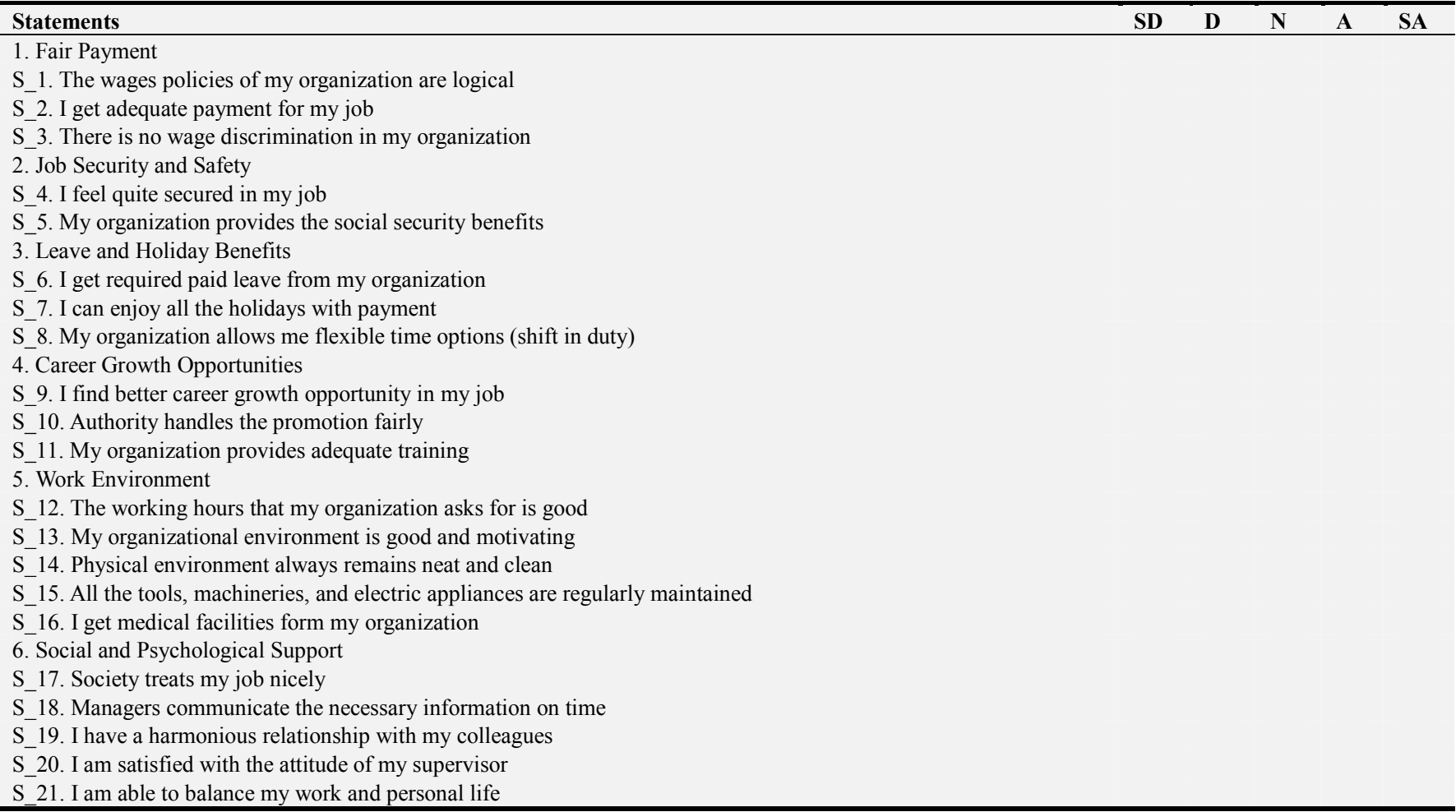

D. Put your comment/opinion regarding the issue of QWL in the RMG Industry.

Thanks for your cooperation!!!

\section{References}

[1] GOB, 2017. Bangladesh Economic Review 2017, Economic Adviser's Wing, Finance Division, Ministry of Finance, Government of the People's Republic of Bangladesh, Dhaka, Bangladesh.

[2] BGMEA, 2017. BGMEA Member's Directory 2017, BGMEA, Dhaka, Bangladesh.

[3] ILO, 2015. The ILO in Bangladesh, International Labour Organization, Dhaka: Regional Office, Bangladesh.

[4] Khatun, F., 2017. Moving forward beyond 2017, Online available from http://www.thedailystar.net/opinion/macro- mirror/moving-forward-beyond-2017-1338796

[5] Parkinson, B., 1996. Emotions are Social, British Journal of Psychology, 87(4), pp.663-683.

[6] Layer, J. K., Karwowski, W. and Furr, A., 2009. The Effect of Cognitive Demands and Perceived Quality of Work Life on Human Performance in Manufacturing Environments. International Journal of Industrial Ergonomics, 39(2), pp.413-421.

[7] Horst, D. J., Broday, E. F., Bondarick, R., Serpe, L. F., and Pilatti, L. A., 2014. Quality of Working Life and Productivity: An Overview of the Conceptual Framework. International Journal of Managerial Studies and Research, 2(5), pp.87-98. 
[8] Mishra, S., 2015. Quality of Work Life (QWL): Concept and Literature Review. Journal of Research Innovation and Management Science, 1(1), pp. 53-57.

[9] Rastegari, M., Khani, A., Parvin, G. and Jalil, E., 2010. Evaluation of Quality of Working Life and Its Association with Job Performance of the Nurses. Iranian Journal of Nursing and Midwifery Research, 15(4), pp.224-228.

[10] Mosadeghrad, A. M., 2013. Quality of Working Life: An Antecedent to Employee Turnover Intention. International Journal of Health Policy Management, 1(1), pp.43-50.

[11] Nanjundeswaraswamy, T. S. and Swamy, D. R., 2012. A Literature Review on Quality of Work Life and Leadership Styles, International Journal of Engineering Research and Applications, 2(3), pp.1053-1059.

[12] Mirkamali, S. M. and Thani, F. N., 2011. A Study on the Quality of Work Life among Faculty Members of University of Tehran and Sharif University of Technology. ProcediaSocial and Behavioral Sciences, 29, pp.179-187.

[13] Bolhari, A., Rezaeean, A. Bolhari, J., Bairamzadeh, S. and Soltan, A. A. 2011. The Relationship between Quality of Work Life and Demographic Characteristics of Information Technology Staffs. International Conference on Computer Communication and Management Proc of CSIT, 5, IACSIT Press, Singapore.

[14] Talebi, B., Bonab, M. P., Zemestani, G. and Aghdami, N., 2012. Investigating the Relationship between the Employee's Quality of Work Life (QWL) and Their Effectiveness in Banking. European Journal of Experimental Biology, 2(5), pp.1839-1842.
[15] Anwar, A. M., Mahmoud K. A., Rusinah, S. and Ahmad, S. M A., 2013. The Drivers of Quality of Working Life (QWL): A Critical Review. Australian Journal of Basic and Applied Sciences, 7(10), pp.398-405.

[16] Subhashini, S. and Gopal, C. S. R., 2013. Quality of Work Life among Women Employees Working in Garment Factories in Coimbatore District, Asia Pacific Journal of Research, 1(12), pp.22-29.

[17] Sharma, N. and Verma, D. S. 2013. Importance of Quality of Work Life in Small Scale Industries for Employees. International Journal of Latest Research in Science and Technology, 2(2), pp.153-156.

[18] Reddy, D. M. L. and Reddy, P. D. M., 2014. Comparative Analysis of Quality of Work Life among Public and Private Sector Bank Employees. International Journal of Organizational Behaviour and Management Perspectives, 2(4), pp.641-648.

[19] Haque, M. E., Rana, M. S. and Abedin, M. Z., 2015. Assessing the Quality of Work Life of Garment Workers in Bangladesh: A Study on Garment Industries in Dhaka City, Global Journal of Management and Business Research: E Marketing, 15(3), pp.63-74.

[20] Begum, F., Ali, R. N., Hossain, M. A. and Shahid, S. B., 2010. Harassment of women garment workers in Bangladesh. Journal of Bangladesh Agricultural University, 8(2), pp.291296.

[21] Weng, Q. X., McElroy, J. C., Morrow, P. C. and Liu, R., 2010 The Relationship between Career Growth and Organizational Commitment, Journal of Vocational Behavior, 77(3), pp.391400 . 